\title{
METAFORY ZWIERZĘCE W BŁOGOSŁAWIEŃSTWIE JAKUBA (RDZ 49, 1-28)
}

Wiedza przyrodnicza, jaką mamy na temat żywych stworzeń, a dotycząca charakterystyki poszczególnych gatunków, ich występowania, znaczenia dla człowieka i roli w ekosystemie często wymaga od nas takiego skonfrontowania tych informacji z danymi przywołanymi przez autora natchnionego, aby nie zdradzić jego zamierzeń. Chodzi tu zwłaszcza o różnice w sposobie patrzenia na świat istot żywych. Ludzie Biblii byli przede wszystkim doskonałymi obserwatorami, przez co ich wiedzę o świecie przyrody i zachodzących w nim procesach możemy określić jako praktyczną. Natomiast współczesny człowiek w dużej mierze jest w tej dziedzinie teoretykiem. W przeciwieństwie do ludzi żyjących w starożytności nie stawia sobie już pytań o przyczynę wielu zjawisk, bo zostały mu one przedstawione i wyjaśnione przez nauki przyrodnicze. ${ }^{1}$ Dlatego jego postrzeganie świata istot żywych nie nosi już znamion owej tajemniczości i dopowiedzeń bazujących na wyobraźni. $Z$ tego powodu staje przed koniecznością nieco innego spojrzenia na perykopy biblijne, w których pojawiają się wzmianki o zwierzętach. W pierwszej kolejności musi się zastanowić, czy przedstawicieli fauny przywołanych w danych perykopach ma postrzegać jako istoty realne, stanowiące jedynie naturalne i właściwe tło dla opisywanej przez hagiografa rzeczywistości, czy raczej jako alegoryczny sposób przedstawienia jakiejś sytuacji, pouczenia lub myśli.

1 Współcześnie opisem reakcji zwierząt i zjawiskami z zakresu ich psychologii zajmuje się etologia, stosunkowo młoda dziedzina wiedzy w zakresie nauk biologicznych; por. J. S o k oł o w s k i, Tajemnice ptaków, Warszawa 1986, s. 6-8. 
Zaprezentowani zostaną ci reprezentanci fauny biblijnej, do których czyni odwołania autor natchniony perykopie $\mathrm{Rdz} 49,1-28$. Charakterystyka zoologiczna tych zwierząt, odnosząca się zwłaszcza do sposobu ich bytowania w naturalnym środowisku, ich fizjologii oraz właściwego dla poszczególnych gatunków systemu zachowań, pozwoli zweryfikować, a może nawet i dotrzeć do nowych pokładów ich teologicznego znaczenia, kryjącego się niewątpliwie w zamyśle autora natchnionego, wzmiankującego o danych gatunkach w omawianym tekście biblijnym. Zanim podjęte zostaną powyższe kwestie warto pokrótce odnieść się do najważniejszych kwestii historyczno-krytycznych związanych z Rdz 49, 1-28.

\section{Rdz 49,1-28 w świetle zagadnień historyczno-krytycznych}

Perykopa Rdz 49,1-28 to oddzielna jednostka literacka, na którą składają się narratywne ramy w postaci wersetów 1-2 i 28 oraz poetycki korpus obejmujący wersety 3-27, przedzielony notą uzupełniającą (w. 18). Co więcej, wersety 3-27 to najdłuższy tekst poetycki w całej Księdze Rodzaju. Jednocześnie jest to także jeden z najdłuższych i najstarszych tekstów poetyckich całej Biblii, gdyż powstanie jego najstarszych fragmentów datuje się na XII-X w. przed Chr. Oryginalny tekst omawianej perykopy nastręcza także wiele trudności, gdyż zawiera mnóstwo niejasnych słów, konstrukcje syntaktyczne czy wręcz całe dwuznacznie brzmiące zdania. Rodzi to problemy z tłumaczeniem i jednoznaczną interpretacją niektórych wypowiedzi. Ze względu na liczne podobieństwa porównywany jest z tzw. Pieśnią Debory (Sdz 5, 14-18) i Testamentem Mojżesza (Pwt 33, 2-29). ${ }^{2}$

Dyskutować można także nad tytułem, jaki wypadałoby nadać omawianemu fragmentowi. Zamiennie określa się go często testamentem, błogosławieństwem lub proroctwem Jakuba. Kontekst, czyli treść Rdz 47,28-31 i Rdz 49,29 - 50,14, pozwala odczytać tę perykopę

2 Por. J. L e m án s k i, Księga Rodzaju rozdziały 37-50. Wstęp. Przekład z oryginału. Komentarz, t. I, cz. 3, Nowy Komentarz Biblijny, Stary Testament, Częstochowa 2014, s. 456-463. 
jako ostatnie słowa ojca Jakuba skierowane do synów na łożu śmierci. W związku z tym można je nazwać ostatnią wola i pouczeniami umierającego patriarchy, czyli Testamentem Jakuba. Na określenie omawianego fragmentu mianem błogosławieństwa wskazywałby z kolei w. 28. Trudno jednak odnieść to określenie do wszystkich wypowiedzi z Rdz 49, 1-28, zwłaszcza że znajdziemy u także swoiste ,antybłogosławieństwa”, jak to względem Rubena (ww. 3-4) oraz Symeona i Lewiego (ww. 5-7). ${ }^{3}$ Analizowaną perykopę da się także nazwać wizją przyszłości, dotyczącą historycznych realiów życia przyszłych plemion Izraela w ziemi Kanaan (por. w. 28a), czyli przypisać jej znamiona proroctwa.

Część poetycka (ww. 3-27) to jedenaście łatwych do wyróżnienia bloków, z których każdy poświęcony jest jednemu z synów Jakuba, a zarazem eponimów przyszłych pokoleń/plemion Izraela. Układ imion ma charakter chiastyczny i oparty jest na pochodzeniu od poszczególnych matek. Zewnętrze bloki to synowie Lei ww. 3-15 oraz Racheli ww. 22-27. Natomiast centralne - to synowie zrodzeni z ich służących: Bilhy (ww. 16-18), Zilpy (ww. 19-20) i znowu Bilhy (ww. 21). ${ }^{4}$

Na tle powyższych zagadnień wyróżnia się metaforyka zwierzęca. Pierwsza wyraźna wzmianka w tym zakresie to w. 9, gdzie Juda określony jest jako młody lew, lew czy wreszcie lwica. Kolejną metaforę tego typu odnajdujemy w w. 14. Odnosi się ona do Issachara nazwanego osłem kościstym. W w. 17 autor natchniony charakteryzuje Dana i przywołuje obraz węża i żmii rogatej. Z kolei w w. 21 mowa jest o Neftalim przyrównanym do łani na wolności. Metaforę zwierzęca odnajdujemy także w w. 27, który dotyczy Beniamina, i jest tu mowa o wilku drapieżnym. W celu lepszego zrozumienia

3 Temat błogosławieństwa obecny jest tylko w wersetach mówiących o Józefie (por. Rdz 49, 22-26). Szczegółowe informacje na temat literackiej formy poszczególnych aforyzmów prezentuje U. S z w a r c, Przesłanie Rdz 49 i Pwt 33. Studium literacko-egzegetyczno-historyczne, Lublin 1997, s. 36-50.

4 Por. J. L e m a ń s k i, Księga Rodzaju rozdziały 37-50. Wstęp. Przekład z oryginału. Komentarz, s. 463-464. 
tych metafor zostanie ukazany sposób postrzegania tych zwierząt w innych tekstach biblijnych w konfrontacji z tym, co o nich mówi współczesna zoologia.

\section{Juda jako lew}

Pierwsza metafora zwierzęca w błogosławieństwie Jakuba zawiera się w słowach: „Judo, młody lwie, na zdobyczy róść będziesz, mój synu: jak lew się czai, gotuje do skoku, do lwicy podobny - któż się ośmieli go drażnić" ( $\operatorname{Rdz} 49,9){ }^{5}$

W kontekście przywołanych słów warto podkreślić, że autorzy biblijni używają aż siedmiu słów na określenie lwa. Trzy z nich zostaje przywołanych w Rdz 49, 9: gûr 'arjēh, 'arjēh, lābî'. Niestety, brak w języku polskim właściwych im odpowiedników. Rzeczownik gûr zwykle opisuje młodego lwa, lwiątko, 'arjēh i kelābî' - dotyczą dorosłych lwów, odpowiednio - samca i samicy. Ponieważ od najdawniejszych czasów człowiek podziwiał lwa za jego siłę, majestat i budzące grozę ryczenie, dlatego nie dziwi to, że spostrzeżenia dotyczące sposobu życia i zachowania tego drapieżnego kota zostały przywoływane na kartach Pisma Świętego. W przywołanym tekście odczytywać je należy zasadniczo w kluczu motywu literackiego służącego wyobrażeniu siły bez strachu, mocy, majestatu, skuteczność, grozy i swoistej drapieżności, gdyż na taką interpretację zdają się wskazywać inne teksty biblijne.

Lew (Panthera leo), rozumiany jako gatunek zwierzęcia, jest najczęściej wymienianym w Biblii przedstawicielem dzikiej fauny terenów biblijnych i obok niedźwiedzia jednym z największych zwierząt drapieżnych tego obszaru. W całym Piśmie Świętym odnotowuje się ok. 140 wzmianek odnoszących się do lwów.

Badania zoologów i archeozoologów pozwalają stwierdzić, że odnoszą się one najprawdopodobniej do lwa azjatyckiego (syn.

5 Wszystkie cytaty biblijne, jeśli inaczej nie zaznaczono, podano za: Pismo Święte Starego i Nowego Testamentu w przekładzie z języków oryginalnych (Biblia Tysiąclecia), Poznań $2000^{5}$. 
perskiego) (Panthera leo persica), którego zasięg występowania w czasach historycznych obejmował teren od dawnej Grecji, przez Azję Mniejszą, Iran, północną Arabię aż po wschodnie Indie. Sądzi się, że prawdopodobnie ostatni przedstawiciel tego podgatunku lwa na terenie dzisiejszego Izraela został zabity w XIII w. po Chr. niedaleko Meggido. Natomiast w Mezopotamii można było go jeszcze spotkać w XIX w. ${ }^{6}$

Przypuszczać również należy, że wspomniana wyżej wielość biblijnych odwołań odnoszących się do lwa mogła wynikać z obserwacji tych kotów. Lwy azjatyckie, mimo że mniejsze od afrykańskich i z krótszą grzywą, były równie jak one groźne dla ludzi oraz hodowanych przez nich stad (por. 1Sm 17, 34-37; Hi 4,10-11; Am 3,12). W czasach biblijnych drapieżniki te miały swoje legowiska w zaroślach nad Jordanem (por Jr 5, 6; 12, 8; 25, 38; 49, 19; 50, 44; Hi 38, 40), gdzie spędzały dzień, zaś nocą wyruszały na łowy. Królowie i władcy Bliskiego Wschodu polowali na nie dla rozrywki i chwytali w pułapki (por. Ez 19,1-9). Król Persji, Dariusz, trzymał je nawet w jaskiniach (por. Dn 6, 16-23). ${ }^{7}$

Prorok Izajasz mówi o lwach na Negebie (Iz 30, 6), na ataki których narażone były karawany kupców przewożących swe towary do Egiptu. Księga Syracha także ukazuje tereny pustynne jako miejsce występowania lwów, przywołując obraz polowania tych drapieżnych kotów na dzikie osły - onagry: „Dziki osioł na pustyni jest żerem dla lwów, a biedni są łupem dla bogatego" (Syr 13, 19). Natomiast Księgi Królewskie trzykrotnie opisują okoliczności, kiedy lew zabija ludzi (1Krl 13, 24; 20, 36; 2Krl 17, 26). Biblia wspomina także o sytuacjach, kiedy lwy ginęły z ręki ludzi. Do najbardziej znanych należy opowiadanie o Samsonie, który bez użycia broni zabił młodego lwa

6 Por. P. F r a n c e, An Encyclopedia of Bible Animals, Tel Aviv 1986, s. 100-103; por. W.W. F e r g u s o n, The Mammals of Israel, Jerusalem 2002, s. 91.

7 Por. L. Ry ke n, J. C. W il hoi t, T. L o n g m a n III, Stownik symboliki biblijnej. Obrazy, symbole, motywy, metafory, figury stylistyczne i gatunki literackie w Piśmie Świętym, Prymasowska Seria Biblijna, Warszawa 1998, s. 1195; por. J.I. P a c k e r, M.C. Te n n e y (red.), Słownik tła Biblii, Prymasowska Seria Biblijna, Warszawa 2007, s. 180. 
(por. Sdz 14, 5nn.). Również Dawid był tym, który skutecznie bronił swojego stada przed lwami i innymi drapieżnymi zwierzętami (1Sm 17, 34-37). Ryczący i czyhający na zdobycz lew jest w Biblii często przywoływany w celu zobrazowania grozy i przemocy, na jaką narażony jest Izrael ze strony swoich wrogów (por. Ps 17, 12; 22, 13; Iz 5, 29; Jr 2, 15). Zwierzę to jest także symbolem siły i odwagi narodu izraelskiego ( $\mathrm{Lb} 23,24 ; 24,9)$, a także uczciwego człowieka: „Ucieka występny, choć go nikt nie goni, lecz prawy jest ufny jak młody lew" (Prz 28, 1). ${ }^{8}$

Księga Przysłów mówi natomiast, że lew „przed niczym się nie cofa" (Prz 30, 30). Nie boi się on nawet ludzi, na co wskazuje cytat z Księgi Izajasza (31, 4): „Albowiem Pan tak powiedział do mnie: Podobnie jak lew albo lwiątko pomrukuje nad swą zdobyczą: gdy przeciw niemu zbierze się tłum pasterzy, on się nie lęka ich krzyku ani się nie płoszy ich hałasem, tak Pan Zastępów zstąpi do boju na górze Syjon i na jego pagórku" (Iz 31, 4).

Ponieważ lew to zwierzę silne, czujne i odważne, co potwierdzają powyższe cytaty, o majestatycznej budowie i pełne dostojeństwa, był na staroży tnym Bliskim Wschodzie łączony z symboliką królewską (por. $1 \mathrm{Krl} 10,18-20)^{9}{ }^{9}$

Zasygnalizowane wyżej bogactwo biblijnych odniesień do lwów ma swe źródło w cechującym autorów natchnionych dobrym zmyśle obserwacji, przekładającym się na znajomość biologii tego gatunku. Świadectwo tego mamy także w analizowanej metaforze Rdz 49, 9, gdzie mowa jest o polowaniu tych dużych kotów. Zoologia wyjaśnia bowiem, że lwy różnią się od innych kotowatych tym, że żyją w stadach i polują grupowo. Stado takie może liczyć od 3 do 30 osobników. Składa się ono ze spokrewnionych samic, ich potomstwa obojga płci i kilku niespokrewnionych ze sobą samców. Taki sposób życia gwarantuje zwiększenie skuteczności pozyskiwania pokarmu oraz większą przeżywalność młodych. Lwy polują głównie na ssaki

8 Por. S. H ała s, Pustynia miejscem próby i spotkania z Bogiem. Wybrane zagadnienia biblijnej teologii pustyni, Kraków 1999, s. 49-50.

9 Por. M. L u r k e r, Słownik obrazów biblijnych, Poznań 1989, s. 111. 
kopytne, takie jak antylopy, zebry, gazele czy bawoły afrykańskie. Gdy brakuje pokarmu, zdarza się im napadać na zwierzęta hodowlane. Łowy odbywają się najczęściej nocą. Biorą w nich udział zazwyczaj samice. W czasie ataku lwy starają się okrążyć ofiarę, lub zagonić ją w pułapkę, np. gęste krzaki, tak by nie miała drogi ucieczki. Zabijanie ofiary odbywa się przez jej przewrócenie i uduszenie. ${ }^{10} \mathrm{Cała}$ ta strategia łowiecka związana jest z tym, że lew jest zwierzęciem o dość masywnej budowie ciała, która trochę utrudnia mu szybki pościg za ofiarą. Często lwy polują także w pojedynkę, podchodząc ofiarę pod wiatr, po to, aby nie wyczuła jego zapachu. Stosują także strategię zasadzki. Nigdy jednak nie czatują na nią przez dłuższy czas w tym samym miejscu, czekając na jej nadejście, tylko krążą po terenie aż do spotkania zwierzęcia, które może stać się ich łupem. ${ }^{11}$

Dla przykładu, autor Księgi Syracha wykorzystuje tę znajomość sposobu ataku tych drapieżnych kotów do metaforycznego przedstawienia mechanizmu działania grzechu i mówi, że są to napaści niespodziewane i nie sposób im sprostać (por. Syr 21, 2). Porównuje on także grzech do lwa czyhającego w zasadzce: ,Jak lew zasadza się na zdobycz, tak grzech na popełniających niegodziwości” (Syr 27, 10).

Opracowania z zakresu zoologii charakteryzują także kolejne etapy polowania lwów. Kot ten zawsze skacze na ofiarę od tyłu, wbijając pazury jednej łapy w okolice jej barku. Drugą natomiast kładzie jej na głowie, chwytając jednocześnie szczękami za kark upolowanego zwierzęcia. Ten silny uścisk łamie kręgi szyjne ofiary, a potężne ściśnięcie szczęk sprawia, że zęby lwa przebijają rdzeń kręgowy, powodując jej natychmiastową śmierć. ${ }^{12}$ Autorzy ksiąg prorockich porównują do polującego lwa samego Boga, gdy objawia On swoją karzącą sprawiedliwość. Potwierdzają to wzmianki w Księdze Jeremiasza (49, 18-19), Ozeasza $(5,14 ; 13,7)$ czy Amosa (3,8; 5, 18-20).

10 Por. E. Go ś c iń s k a (red.), Sawanna Afrykańska. Encyklopedia dzikich zwierząt Larousse, Warszawa 1992, s. 25-44.

11 Por. A. Z a s i e c z n y (red.), Historia naturalna. Kregowce I. Ssaki i ptaki, Poznań 1989, s. 100.

12 Por. tamże, s. 100-101. 
Ozeasz w ten sposób sugestywnie ukazuje rozmiar Bożego gniewu i wielkość kary, jaka czeka tych, którzy nastają na Jego wybrańców: „Ja bowiem jestem lwem dla Efraima, młodym lwem - dla domu judzkiego; Ja, Ja rozszarpię, a potem odejdę, uniosę zdobycz, a nikt nie ocali” (Oz 5, 14; por. 13, 7; Hi 10, 6). Również u Izajasza (31, 3-5) Bóg stający w obronie Izraela jest przyrównany do lwa broniącego swej zdobyczy, jak wskazuje przywoływany już w. 4.

Odwołania do lwa znajdują swe odniesienie zarówno w metaforach i porównaniach charakteryzujących postępowanie ludzi, jak i we wzmiankach dotyczących działania Boga. Co więcej, wartość symboliczna motywu lwa w Biblii ma charakter ambiwalentny. Zwierzę to jest bowiem źródłem kontrastujących ze sobą metafor: dobra i zła, boskości i zwierzęcości, miłości i krwiożerczości, łagodności i drapieżności. ${ }^{13}$ Jest symbolem królewskiego majestatu i potęgi, ale także nieokiełznanej drapieżności i krwiożerczości. Na starożytnym Bliskim Wschodzie był on atrybutem królów i niektórych bóstw, co każe upatrywać w biblijnych odwołaniach do tego przedstawiciela świata fauny uniwersalnej symboliki i wspólnych motywów, z których korzystają również autorzy biblijni. ${ }^{14}$

W związku z powyższym stopniowane przywołanie w Rdz 49, 9 poszczególnych form rozwojowych lwa począwszy od lwiątka do postaci dorosłej, to zapewne także odwołanie autora natchnionego do znanego ze świata natury stopniowego wzrostu siły i coraz większej dominacji dorastającego lwa w stadzie. Jednocześnie młode lwiątko jest tu synonimem młodzieńczej siła i fantazji. Natomiast dorosłe zwierzęta, a zwłaszcza lwica, symbolizuje przemyślana strategia działania, która w przypadku zwierzęcia jest ukierunkowana na odniesienie łowieckiego sukcesu. Dlatego też niniejszą metaforę można interpretować jako stopniowe dochodzenia Judy do władzy i znaczenia wśród pozostałych braci (pokoleń/plemion Izraela), co

13 Por. W. K o p a 1 i ń s k i, Stownik symboli, Warszawa 2012, s. 194.

14 Por. R. J a s n o s, Zoomorficzne aspekty wyobrażenia Boga w Starym Testamencie, w: L. K o s t u c h, K. R y s z e w s k a (red.), Zwierze jako sacrum w pradziejach i starożytności, t. 1, Kielce 2006, s. 168-169. 
wydaje się potwierdzać dalsza jego część: „Nie zostanie odjęte berło od Judy ani laska pasterska spośród kolan jego, aż przyjdzie ten, do którego ono należy, i zdobędzie posłuch u narodów! Przywiąże on swego osiołka w winnicy i źrebię ośle u winnych latorośli. W winie prać będzie swą odzież, i w krwi winogron - swą szatę" (Rdz 49, 10-11). Wzmianka o obecności osła w winnicy może być odczytana w kontekście późniejszych tekstów biblijnych, jako zapowiedź mesjańskiego królestwa, czasu obfitości i pokoju. Osioł w Biblii to symbol pokory i wytrwałej służby, co znalazło wyraz w proroctwie Zachariasza (Za 9, 9): „Oto Król twój idzie do ciebie, sprawiedliwy i zwycięski. Pokorny - jedzie na oślątku, źrebięciu oślicy”. ${ }^{15}$ Podkreśla się w ten sposób także pokojowe zamiary zapowiadanego tu króla ${ }^{16}$ bo władca udający się na wojnę dosiadał konia. ${ }^{17}$ Natomiast zapowiadane pozostawianie owego osiołka tuż przy winorośli, czyli stwarzanie lwu możliwości pożywiania się nią, czego normalnie się raczej unika, pozwala przypuszczać, że wraz z nadejściem zapowiadanego króla nastanie sytuacja charakteryzująca się nadmiarem dóbr, wszelkim dostatkiem i bogactwem pożywienia (por. $\mathrm{Rdz} 49,12$ ). $\mathrm{Na}$ takie wnioskowanie pozwala wzmianka o mleku, symbolizującym krainę piękną i urodzajną (por. Wj 3, 8; Kpł 20, 24). Natomiast obfitość wina wskazuje na radość, brak trosk, wesele, pełnię szczęścia i błogosławieństwa (por. Za 10, 7; Ps 104, 15; Prz 31, 6; Pwt 28, 39; Iz 16, 10; Jr 48, 33).

15 Por. J.I. P a c k e r, M.C. Te n n e y (red.), Stownik tła Biblii, s. 173-174.

16 Do tego proroctwa nawiązują wszyscy ewangeliści, opisując uroczysty wjazd Jezusa do Jerozolimy, który w ten sposób chce pokazać właściwy wymiar swojej mesjańskiej misji. Nie przybywa On jako wojowniczy władca, lecz pełen pokory Książę Pokoju siedzący na młodym oślęciu. Co więcej, jest to jedyny przypadek, kiedy Ewangelie mówią o Jezusie dosiadającym osła (por. Mk 11, 1-7; Mt 21, 2-7; Łk 19, 30; J 12, 14-15).

17 Por. W.R. Farmer i in. (red.), W. Chrostowski (red. wyd. pol.), Międzynarodowy Komentarz do Pisma Świętego. Komentarz katolicki i ekumeniczny na XXI wiek, Warszawa 2000, s. 1070; por. R.C. F u 11 e r, L. J o h n s t o n, C. K e a r n s, A New Catholic Commentary on Holy Scripture, Nashville-New York 1975, s. 731. 
Proroctwo Rdz 49, 8-12 uzyska wypełnienie w osobie króla Dawida i jego potomków, zaś absolutną pełnię w Mesjaszu - Jezusie Chrystusie. ${ }^{18}$ Do słów umierającego Jakuba, przepowiadającego swoim dwunastu synom przyszłość ich potomstwa, nawiąże bowiem w następujący sposób autor Apokalipsy, wyjaśniając meandry Bożych interwencji w świecie: „Oto zwyciężył Lew z pokolenia Judy, Odrośl Dawida, tak że otworzy księgę i siedem jej pieczęci” (Ap 5, 5). ${ }^{19}$

\section{Issachar jako osioł}

Kolejny cytat z proroctwa Jakuba zawierającym metaforę odwołującą się do świata zwierząt stanowią słowa: „Issachar - osioł kościsty, będzie się wylegiwał ufny w swe bezpieczeństwo. Widzi on, że dobry jest spoczynek, a kraj uroczy; ale będzie musiał ugiąć swój grzbiet pod brzemieniem i stanie się niewolnikiem, pędzonym do pracy" ( $\mathrm{Rdz} 49,14-15)$.

Osioł domowy (Equus africanus f. asinus) został udomowiony prawdopodobnie ok. 3 tysiąclecia przed Chr., a związane to było $\mathrm{z}$ jego użyciem jako zwierzęcia pod wierzch oraz siły pociągowej (por. $\operatorname{Rdz} 22,3 ; 42,26-27$; 1Sm 25, 18). Miało to miejsce na długo wcześniej zanim został udomowiony wielbłąd. ${ }^{20} \mathrm{Za}$ jego przodka uważa się dzikiego osła afrykańskiego (Equus africanus), który w czasach historycznych zasiedlał suche tereny stepowe o ubogiej roślinności w Afryce, na Półwyspie Arabskim oraz wschodnie wybrzeże Morza Śródziemnego. Zwierzęta te charakteryzowała czerwono-szara barwa sierści, ${ }^{21}$ co też znalazło odzwierciedlenie w biblijnym nazewnictwie osła domowego - hămôr, którą zapewne utworzono nawiązując do umaszczenia (rdzeń $h m r$ - „czerwony”) jego dzikiego przodka.

18 Więcej na ten temat: J. S y n o w i e c, Mesjanizm w Rdz 49, 8-12? w: S. Ł a c h, M. F i 1 i p i a k (red.), Mesjasz w biblijnej historii zbawienia, Lublin 1974, s. 30-40.

19 Por. D. F or s t n e r, Świat symboliki chrześcijańskiej, Warszawa 1990, s. $276-277$.

20 S. J a n k ow s k i, Geografia biblijna, Warszawa 2007, s. 87.

${ }^{21}$ Por. A. L a s ot a-M o s k a le w s k a, Zwierzęta udomowione w dziejach ludzkości, Warszawa 2005, s. 190. 
Osioł był nieodłącznie związany z życiem codziennym w Izraelu. Hodowano go powszechnie i był w posiadaniu niemal każdej rodziny, a związane to było z tym, że nie miał on zbyt dużych wymagań pokarmowych i był odporny na niesprzyjające warunki atmosferyczne. Osły i oślice wykorzystywano jako zwierzęta pociągowe. Te ostatnie można też było doić. Nawet ludzie bogaci podróżowali na osłach, a wyróżnikiem ich pozycji było posiadanie zwierzęcia o białej sierści (por. Sdz 5, 10-11). Jeżdżono na oślicach, gdyż były one bardziej posłusznymi wierzchowcami niż osły, choć i one nie zawsze bywają łagodne (por. Lb 22, 21-30). ${ }^{22}$

Issachar jest piątym syn Lei i dziewiątym synem Jakuba (por. Rdz 30, 14-18; 35,23). Ziemia, którą otrzyma według błogosławieństwa Jakuba Issachar, jest dobra i daje spoczynek. W związku z tym musi mieć najlepsze pastwiska i ziemię uprawną. Miejscem takim w Izraelu jest równina Esdraelon (Jezreel) (por. Pwt 33, 18-19; 1Krn 12, 40). Przydział Issachara opisany jest w Joz 19, 17-23 i obejmował on wspomniany teren. Issachar jednak, aby mieć ów spoczynek, podda się ciężkiej przymusowej pracy. Na zrozumienie metafory osła w proroctwie Jakuba swoiste światło rzucają też wzmianki o tym zwierzęciu w Księdze Syracha. W Syr 33, 25 jest on przedstawiony jako ktoś podwładny, niedoceniany, nadający się jedynie do ciężkiej pracy. W tym fragmencie zestawia się osła z niewolnikiem. Inny fragment pokazuje to zwierzę jako przeciwieństwo lwa (por. Syr 13, 19), podkreśla się jego bierność i niską pozycję społeczną, osioł jest metaforycznym wyrazem człowieka biednego i wzgardzonego.

\section{Dan niczym wąż, żmija jadowita}

Kolejna metafora w proroctwie Jakuba, mająca swe zakorzenienie w odwołaniu do fauny biblijnej, występuje w przypadku słów odnoszących się do Dana. Werset ten brzmi następująco: „,Dan] będzie on jak wąż na drodze, jak żmija jadowita na ścieżce, kąsająca pęciny

22 Por. P.C. B o s a k, Leksykon wszystkich zwierząt biblijnych, Kraków 2018, s. $423-424$. 
konia, z którego jeździec spada na wznak" (Rdz 49, 17) i pojawia się w nim wyraźne nawiązanie do węży, które od zawsze fascynowały człowieka, budząc jednocześnie przerażenie. Podziwiano je za ich tajemniczość i indywidualizm, wyrażający się choćby w jakże odmiennym od większości żywych stworzeń sposobie poruszania się. Co więcej, te pozbawione rąk i nóg istoty, nie mające też powiek, małżowin usznych i nie wydające innych odgłosów poza syczeniem zadziwiały ludzi swą nieustraszonością, zwinnością, nieruchomym trwaniem i błyskawicznym atakiem, niezależnością, a także zazwyczaj samotniczym trybem życia. Obawiano się ich, bowiem niosły ludziom i zwierzętom śmierć przez uduszenie lub jadowite ukąszenie. W wyniku ścieranie się tych ambiwalentnych emocji, fascynacji i obaw, człowiek uczynił z węża symbol pierwotnych sił kosmicznych, mocy uzdrowicielskich, samorództwa, odmłodzenia, płodności, podstępu, przebiegłości i inteligencji.

Warto się zatem nieco dłużej zastanowić nad tymi cechami biologicznymi węży, które stanęły u podstaw tak złożonej symboliki. Pierwsze, co przykuwa uwagę w wyglądzie tego zwierzęcia, to jego wydłużone i pozbawione kończyn ciało oraz bezszelestne pełzanie. Wyciągnięty wąż przypomina linię prostą i to zapewne sprawiło, że zaczęto postrzegać w nim symbol linii czasu, a zwinięty upodabnia się do koła. Znalazło to odzwierciedlenie w wyobrażeniach Uroburosa, węża połykającego własny ogon, będącego symbolem stałego powtarzania się cyklu życia. ${ }^{23}$

Wąż to także zwierzę, które orientuje się w otoczeniu nie tylko za pomocą zmysłu wzroku, ale w dużej mierze dzięki czułości swego rozdwojonego języka, który jest także częścią aparatu węchowego. Ponadto ma on bardzo słabo rozwinięty słuch, co rekompensuje mu z kolei przystosowanie do odbierania wibracji z podłoża. Niemałe wrażenie robi także sposób odżywiania się tego gada. Połyka on

23 Por. S. K o b i e l u s, Bestiarium chrześcijańskie. Zwierzęta w symbolice i interpretacji. Starożytność i średniowiecze, Warszawa 2002, s. 324-325; por. L. I m p e 11 u s o, Natura i jej symbole. Rośliny i zwierzęta. Leksykon: historia, sztuka, ikonografia, Warszawa 2006, s. 270. 
bowiem swą zdobycz w całości. Wąż, w zależności od gatunku, dusi swe ofiary (np. pyton) lub zabija za pomocą bardzo szybko działającego jadu. W związku z tym w wężach jadowitych zaczęto widzieć symbol ognia. Natomiast wylinki węży, czyli okresowa zmiana skóry, uczyniła z tych zwierząt symbole odradzania się i nieśmiertelności. Na kanwie tego zrodziło się z kolei przekonanie, że gady te mogą uzdrawiać. Dlatego też hodowano je w świątyniach poświęconych Asklepiosowi i wykorzystywano w zabiegach leczniczych. Także ze względu na owe „odradzanie się” oraz falliczny kształt, wąż był wiązany z kultem płodności. ${ }^{24}$

Węże jadowite przyjęło się uważać za istoty szczególnie podstępne, wyrafinowane i okrutne. Jad służy im jednak do zdobywania pożywienia i obrony. Działa on bardzo szybko, co niewątpliwie oszczędza ich ofiarom męczarni. Gady te w większości przypadków unikają człowieka, a polując głównie na gryzonie, przyczyniają się do zachowania równowagi biologicznej w przyrodzie..$^{25}$

W kontekście identyfikacji konkretnego przedstawiciela fauny biblijnej, który kryje się pod hebrajskim terminem šepîpōn (hapax legomenon) można z dużym prawdopodobieństwem wnioskować, że tym gatunkiem węża jest żmija rogata (Cerastes cornutus), jeden $\mathrm{z}$ bardziej jadowitych węży zamieszkujących Izrael. Osiąga on długość do $80 \mathrm{~cm}$, ma jasną skórę w kolorze piasku, więc łatwo może się w nim zaczaić na ofiarę. Niewprawne oko z trudem wtedy dostrzega tę żmiję. Jest czujna i błyskawicznie rzuca się na zdobycz. ${ }^{26}$

Dyskutowane mogą być także dwa inne gatunki tego jadowitego gada - Vipera lebetina i Vipera xanthina.$^{27}$ Pierwszy z nich to żmija lewantyńska spotykana w Europie, Azji i w Afryce. Występuje ona także na niektórych wyspach Morza Egipskiego, na Cyprze w Turcji, Libanie, Syrii, Izraelu, Iraku, Iranie, Armenii i Pakistanie. Osiąga

24 Por. T. K a l e t a, Religie i zwierzęta. Szkice do wspólnego portretu, Warszawa 2013, s. 134-135.

25 Por. W. J a r o n i e w s k i, Gady jadowite, Warszawa 1973, s. 15-16.

26 Por. P. F r a n c e, An Encyclopedia of Bible Animals, s. 10-11.

27 Por. tamże, s. 152-154. 
długość do 1,4 m. Ubarwienie ma dość zmienne. Okazy z terenów europejskich mają grzbiet szary, szaro-żółtawy lub jasnobrunatny z dwoma szeregami ciemnych plam ustawionych naprzeciw siebie lub naprzemiennie. Czasem plamy te łączą się ze sobą, dając falistą pręgę na grzbiecie. Na głowie u tego gatunku występuje plama przypominająca odwróconą piątkę rzymską, a za nią dwie ukośne plamki. Strona brzuszna tego gada jest biaława, przechodząca w szarobrunatną, jednolita lub z ciemnymi plamami. Żmija lewantyńska prowadzi nocny tryb życia. Zbliża się chętnie do zabudowań ludzkich i osiedla w ogrodach lub w winnicach. Żywi się drobnymi ssakami, głównie gryzoniami. Chociaż wydaje się stosunkowo leniwa i powolna, potrafi na krótkie odległości rozwijać dość znaczną szybkość. Silny jad i długie zęby jadowe powodują, że jej ukąszenie jest dla człowieka niebezpieczne. ${ }^{28}$

Z kolei żmija bliskowschodnia (Vipera xanthina) występuje od Armenii i północnego Iraku przez Syrię, Liban, po Izrael i Jordanię. Można ją spotkać wzdłuż dolin rzecznych pokrytych roślinnością. Unika terenów pustynnych. Często występuje wśród upraw rolnych, a nawet w ogródkach obok mieszkań ludzkich. Prowadzi nocny tryb życia. Jest czujna i bardzo szybko atakuje zakłócającego jej spokój. Osiąga długość 0,7-0,9 m, niekiedy 1,2 m. W Izraelu i w krajach sąsiednich żyje podgatunek palestyński tej żmii (Vipera xanthina palestinea) (żmija palestyńska). Znajduje się ona na pierwszym miejscu w statystykach ukąszeń przez węże w tych krajach. Jad ma bardzo silny, a śmiertelność w wyniku ukąszeń sięga 5\% przypadków nieleczonych $\mathrm{w}$ porę odpowiednią surowicą przeciwjadową. ${ }^{29}$

Wąż w Biblii wymieniany jest dosyć często. Większość tych wzmianek ma wydźwięk negatywny i wiąże się z postrzeganiem tych gadów jako stworzeń niebezpiecznych, zdradliwych, przebiegłych, których gwałtowny atak zazwyczaj kończy się śmiercionośnym

28 Por. W. J a r o n i e w s k i, Jadowite węże świata, Warszawa 1988, s. 76-77.

29 Por. tamże, s. 77. 
ukąszeniem..$^{30}$ Znajduje to potwierdzenie m.in. w słowach patriarchy Jakuba skierowanych do Dana (Rdz 49,17). Dan okaże się bardzo przydatny, gdyż będzie działał w sposób podobny do zachowania węża. Niczym żmija rogata mógł się zaczaić na wrogów i niejako ukąsić konia, powodując upadek jeźdźca. Tak więc, mimo niewielkiej liczebności pokolenie Dana miało być dla przeciwników Izraela tak groźne jak żmija rogata. Porównane zostało do węża, żmii na drodze należy w tym przypadku interpretować przede wszystkim jako przymiot przebiegłości i roztropności ${ }^{31}$ dzięki której to małe pokolenie będzie niebezpieczne dla silniejszych od niego wrogów. Dobrze oddaje to historia przejścia Danitów z południa na północ Palestyny i opanowania nowego terytorium wraz z miastem Lajisz leżącym w okolicach źródeł Jordanu (por. Sdz 18, 11-29).

\section{Neftali niczym lania}

Tłumaczenie wersetu Rdz 49, 21 jest dyskutowane. Przekład Biblii Tysiąclecia przywołuje tu roślinę - okazałe drzewo właściwe dla flory Izraela - terebint, czyli pistację palestyńską (Pistacia palaestina Boiss.): „Neftali - jak rozłożysty terebint, dający miłe przepowiednie". Inni tłumaczą ten werset, przywołując określony gatunek zwierzęcia: „Neftali - łania puszczana swobodnie, która rodzić będzie piękne jelonki". ${ }^{32}$

W ramach uściślenia zoologicznego należy podkreślić, że chodzi tutaj prawdopodobnie o gatunek daniela (Dama dama), ssaka

30 Zagadnienie znaczenia węża w tradycji biblijnej i rabinicznej obszernie omawia J. Tabick. Tematykę tę rozpatruje w trzech aspektach: a) węża jako sługi Bożego; b) węża jako symbol buntu przeciwko Bogu oraz c) węża jako stworzenia Bożego; por. J. T a b i c k, The Snake in the Grass. Problems of Interpreting a Symbol in the Hebrew Bible and Rabinic Writings, Religion 16/1986, s. 155-167.

31 Do tej cechy przypisywanej wężom odwoła się także Jezus w słowach pouczenia skierowanych do uczniów: „Oto Ja was posyłam jak owce między wilki. Bądźcie więc roztropni jak węże, a nieskazitelni jak gołębie!” (Mt 10, 19).

32 Por. J. L e m a ń s k i, Księga Rodzaju rozdziały 37-50. Wstęp. Przekład z oryginatu. Komentarz, s. 453. 
z rodziny jeleniowatych. Jego naturalny zasięg występowania obejmuje tereny Azji Mniejszej, w tym Ziemię Świętą, co pozwala przypuszczać, że powszechnie występował on na tym obszarze w czasach historycznych. Natomiast południowa granica występowania jelenia szlachetnego (Cervus elaphus) obejmuje tereny w pobliżu Morza Czarnego, co sprawia, że jego obecność w starożytnym Izraelu może podlegać dyskusji. Dodać trzeba, że daniel jest do niego podobny i wiedzie analogiczny tryb życia. Daniel jest zwierzęciem średniej wielkości, nieco mniejszy od jelenia szlachetnego. Cechuje go ubarwienie czerwonawo-brunatne z bardzo charakterystycznymi białymi plamkami ułożonymi w podłużnych rzędach. Spód ciała daniela jest barwy białej, na zadzie występuje biała plama z ciemnym obrzeżem, tzw. lustro. Ogon od góry ma barwę czarną, zaś od spodu jest biały. Tak jak u innych przedstawicieli jeleniowatych, samiec ma poroże, które co roku zrzuca. ${ }^{33}$ Są to smukłe łopaty z małymi odrostkami bocznymi. Odchodzą na boki, a następnie łukowato wywijają się ku górze sprawiając wrażenie uniesionych rąk. Samica daniela nie ma poroża. ${ }^{34} \mathrm{Na}$ omawianym terenie dyskutuje się zwłaszcza występowanie daniela mezopotamskiego (Dama mesopotamica), dawniej traktowanego jako podgatunek daniela zwyczajnego, co znajdowało odzwierciedlenie w nomenklaturze zoologicznej, która określała go mianem Dama dama mesopotamica. ${ }^{35}$

Biblijna symbolika łani (hebr. 'ajjālâ) jest bardzo bogata. Opierając się na metaforyce Psalmów (por. Ps 41, 2), oznacza tęsknotę człowieka za orzeźwieniem, jakie może dać bliskość Boga, w innych za zaś miejscach punktem wyjścia do budowy skojarzeń symbolicznych jest zwinność, prędkość i smukły, delikatny wygląd (por. Pnp 2, 9). Wypowiedź Jakuba o tym pokoleniu jest dla nas dzisiaj niezrozumiała. Łania jest może godłem tego pokolenia, nie wynikającym jednak

33 Por. W.W. F e rg u s o n, The Mammals of Israel, s. 99-100.

34 Por. A. La s o t a-Mos k a lew s k a, Archeozoologia. Ssaki, Warszawa 2008, s. 282.

35 Por. W. C i chock i i in., Polskie nazewnictwo ssaków świata, Warszawa 2015, s. 175. 
z charakterystycznych cech Neftalitów. Mieszkali oni na zachodnim brzegu jeziora Genezaret i dalej na północ, co pokrywało się w czasach historycznych z naturalnym zasięgiem i występowaniem danieli mezopotamskich, które zamieszkiwały teren Górnej Galileii, okolice góry Tabor, Karmelu i równinę nadmorską (Emeq Hefer) ${ }^{36}$

\section{Beniamin niczym wilk drapieżny}

Ostatnia z metafor zwierzęcych w proroctwie Jakuba dosyła do zwierzęcia, jakim jest wilk (Canis lupus), gdyż czytamy: „Beniamin wilk drapieżny, co rano rozrywa zdobycz, a wieczorem rozdziela łupy" (Rdz 49, 27). W wyjaśnieniu okoliczności, które mogły stać za takim obrazem, pomagają nam inne teksty biblijne. Charakteryzują one to plemię jako małe, ale jednocześnie wyróżniające się znacznym zapałem wojennym, czego dowodzą wojny Beniaminitów z Moabitami (por. Sdz 3, 15-30), Kananejczykami (por. Sdz 5,14) czy też innymi pokoleniami izraelskimi (por. Sdz 19-20). Z tego też powodu zostało ono zapewne porównane do wilka (hebr. ze'éb) - szybkiego i groźnego zwierzęcia, którego strategie łowieckie musiały być dobrze znane ludziom Biblii (por. Ez 22, 27; So 3, 3; Ha 1, 8). ${ }^{37}$

Wilki to zwierzęta wykazujące wiele przystosowań do prowadzonego przez siebie sposobu życia. Tryb ich życia, a zwłaszcza sposób zdobywania pokarmu sprawił, że postrzega się je w Biblii jako metaforę śmiałości, krwiożerczości i bezwzględności, zwłaszcza w konfrontacji z owcami, będącymi z kolei symbolem naiwności, ufności i bezbronności (por. Mt 10,16). Zwierzęta te w starożytności występowały powszechnie w Ziemi Świętej i często dziesiątkowały pogłowie hodowanych wtedy zwierząt. Do dzisiaj na terenie Izraela odnotowuje się występowanie dwóch podgatunków wilka (Canis lupus). Są to wilk arabski (Canis lupus arabs) oraz wilk indyjski ( $\mathrm{Ca}$ nis lupus pallipes). Pierwszego z nich spotkać można na Wzgórzach

\footnotetext{
36 Por. W.W. F e rg u s o n, The Mammals of Israel, s. 99.

37 Więcej na temat biblijnej symboliki wilka A.M. W a j d a, Szkice z biblijnego zwierzyńca, Kraków 2016, s. 109-110.
} 
Golan i w Judei, rzadziej w północnej części Negevu i Doliny Arava. Drugi zaś przemierza pustynne wzniesienia i wadi południowej części Doliny Arava. ${ }^{38}$ Swoiste potwierdzenie takiego występowania omawianego podgatunku znajdujemy w Księdze Jeremiasza, gdzie czytamy o wilku stepowym $(\operatorname{Jr} 5,6) .{ }^{39}$

Wilk (Canis lupus) to ssak (Mammalia) należący do rzędu Carnivora - drapieżnych i rodziny Canidae - psowatych. ${ }^{40}$ Jest on typowym i największym przedstawicielem tej rodziny. ${ }^{41}$ Długość głowy i tułowia dorosłego wilka (samica jest nieco mniejsza od samca) wynosi ok. 100-130 (160) cm, zaś wysokość w kłębie ok. 80-85 (100) cm. Wilki ważą od 30-60, wyjątkowo do $75 \mathrm{~kg}$. Zwierzęta te były przystosowane do drapieżnego sposobu życia. Mają szczupłe, umięśnione ciało i długi (30-50 cm), puszysty i najczęściej ciężko zwisający ogon używany do utrzymywania równowagi i komunikowania się. Cechuje je palcochodność i długie, muskularne łapy, dzięki którym zwiększa się długość kroku i szybkość poruszania się. Innym uposażeniem wilków, jak i innych przedstawicieli rodziny psowatych, jest posiadanie znakomicie rozwiniętego zmysłu węchu oraz mocna budowa szczęk. U wilków wyposażone są one w 42 spiczaste zęby, w tym w cztery kły służące do przebijania ofiary. Kły u tych zwierząt są długie i grube, a łamacze silne. Powoduje to, że takimi szczękami mogą one z łatwością zmiażdżyć kość udową dużego ssaka kopytnego np. dorosłego łosia lub jelenia. Nacisk szczęk wilka na jednostkę powierzchni wynosi $15 \mathrm{~kg} / \mathrm{cm}^{2}$. O przystosowaniu do drapieżnego trybu życia świadczą również duże oczy umieszczone z przodu głowy oraz sterczące, spiczaste uszy. ${ }^{42}$

38 Por. W.W. F e r g u s o n, The Mammals of Israel, s. 72-73.

39 Por. S. H a ł a s, Pustynia miejscem próby i spotkania z Bogiem, s. 51.

40 Por. M. S t ę p le w s k a, R. M i to r aj (red.), Encyklopedia szkolna. Biologia, Kraków 2004, s. 728.

41 A. R a j s k i, Zoologia. Część systematyczna, t. 2, Warszawa 1988, s. 526.

42 Por. B. B aranowski, E. Dedo, Z. S i ew ak-S ojka (red.), Encyklopedia przyrody, Bielsko Biała 2006, s. 252; por. A. R aj s k i, Zoologia. Czesść systematyczna, s. 526. 
Wilki polują głównie na zwierzęta kopytne, chociaż nie gardzą także drobnymi gryzoniami, ptakami i ich jajami, jaszczurkami, a nawet owadami. ${ }^{43}$ Polują również na zwierzęta domowe. Wilki żyją i polują w stadach (watahach) liczących 20 i więcej osobników. Umożliwia to skuteczne polowanie na duże zwierzęta oraz obronę przed atakami obcych wilków. ${ }^{44}$ Polowania te odbywają się zbiorowo, a poszczególne osobniki w grupie mają ściśle wyznaczone funkcje. Jedne wilki zaczynają pogoń za ofiarą, potem zastępują je następne, a jeszcze inne zabijają umęczone pościgiem zwierzę. Zazwyczaj polowania zaczynają się o zmierzchu i trwają całą noc. ${ }^{45}$ Składają się one z cichego, ostrożnego podejścia i krótkiej, intensywnej pogoni. ${ }^{46}$ Również autorzy biblijny wykazują się dobrą znajomością pory żerowania wilków i wskazują, ze jest to czas nocy (por. Ha 1, 8; So 3,3). ${ }^{47}$

Stada wilków zachowują ścisłą hierarchię społeczną. Całemu stadu przewodzi jedna para, samiec - basior i samica - wadera. Zazwyczaj tylko ta para się rozmnaża. Natomiast pozostałe wilki stoją niżej w hierarchii i dzielą się na osobniki dominujące i podporządkowane. Hierarchia w stadzie jest utrzymywana przez ustalone postawy i zachowania - np. szczerzenie zębów, kładzenie uszu. Informują one o strachu lub podporządkowaniu się i powodują, że każdy członek stada zna w nim swoje miejsce. ${ }^{48}$ Wilki porozumiewają się także za pomocą pięciu różnych rodzajów głosów (skomlenie, warczenie, szczekanie, popiskiwanie i wycie). ${ }^{49}$

43 Por. E. D r e y e r, W. D r e y e r, Las, Warszawa 1995, s. 438.

44 Por. B. B a r a now sk i, E. D ed o, Z. S i e wak-S ojk a (red.), Encyklopedia przyrody, s. 252.

45 Por. S. H o f m a n, Zwierzęta świata, Kraków 2003, s. 103.

46 A. R a j s k i, Zoologia. Czesść systematyczna, s. 528.

47 Por. S. H a ł a s, Pustynia miejscem próby i spotkania z Bogiem, s. 51.

48 Por. B. B a ra now s k i, E. D e d o, Z. S i ew a k-S ojk a (red.), Encyklopedia przyrody, s. 252.

49 Por. S. H o f m a n, Zwierzęta świata, s. 103; Najbardziej charakterystyczne jest wycie, które może być słyszalne przez człowieka z odległości ponad $8 \mathrm{~km}$. Trwa ono od 1/2-11 sekund, ma częstotliwość dźwięku rzędu 150-780 Hz i obejmuje ponad dwanaście tonacji. Wyjąc, wilki sygnalizują swoją obecność sąsiednim watahom. Natomiast szczekanie wilka oznacza alarm, skomlenie - przyjaźń, 
W sąsiedztwie człowieka wilk jest zwierzęciem nocnym. Gdy czuje się zupełnie bezpieczny pozostaje aktywny także w dzień. Poza okresem rozrodczym prowadzi koczowniczy tryb życia. Wilk biega szybko na długich dystansach, nie zmieniając rodzaju biegu. W razie potrzeby rozwija prędkość w granicach $55-60 \mathrm{~km} / \mathrm{h}$. W pogoni za zwierzyną potrafi przebyć $160 \mathrm{~km}$ w ciągu jednej nocy. Bardzo dobrze pływa. Jest silny i wytrzymały. W pysku lub na grzbiecie przenosi zwierzę wielkości owcy na odległość kilku a nawet kilkunastu kilometrów. Może także głodować w ciągu kilkunastu dni. ${ }^{50}$

Opisane wyżej zachowanie drapieżnego wilka doskonale pasuje do dziejów pokolenia Beniamina w czasach Sędziów oraz w początkach monarchii (por. Sdz 3,15; 5,14; 1Sm 9,1.21; 2Sm 2,25; Ps 68,28).

Błogosławieństwo Jakuba (49,1-28) stanowi jeden z pierwszych zapisów, w których pojawiają się nazwy zwierząt i odniesienia do ich specyficznych cech. Te odwołania do świata fauny są niewątpliwie potwierdzeniem dobrej znajomości świata przyrody, która cechuje autora natchnionego. Świadczą o umiejętności wnikliwej obserwacji zwierząt, czego wyrazem jest przede wszystkim znajomość ich określonych zachowań, związanych ze sposobem ich życia. Zapoznanie się egzegetów z charakterystyką zoologiczną zwierząt pojawiających się w perykopie Rdz 49,1-28 jest cennym przyczynkiem do lepszego jej zrozumienia i pozwala jeszcze wyraźniej ukazać różnice między każdym pokoleniem, które autor natchniony charakteryzuje przez konkretną metaforę zwierzęcą.

Anna Maria WAJDA

warczenie świadczy o niezadowoleniu i jest ostrzeżeniem, zaś popiskiwanie to znak podporządkowania lub przyjaźni. Jako ciekawostkę warto dodać, że każdy osobnik ma charakterystyczny tembr głosu, który doskonale rozpoznają współtowarzysze; cyt. za: C. N i c olle (red.), Tajga. Encyklopedia dzikich zwierząt, Warszawa 1997, s. 13-19.

50 A. R a j s k i, Zoologia. Część systematyczna, s. 527. 
Słowa kluczowe: błogosławieństwo Jakuba, metafory zwierzęce, lew, osioł, wąż, łania, wilk

Keywords: Jacob's blessing, animal metaphor, lion, ass, snake, doe, wolf

\section{Animal Metaphors in the Blessing of Jacob (Gen 49:1-28)}

\section{Summary}

The relatively numerous references to animals in the blessing of Jacob (Gen 49: 1-28) show that the biblical author had a broad knowledge of nature. According to the current classification of living organisms and method of research used by modern zoology, it is stated that these observations do not have the characteristics of scientific research. In spite of this, they are the evidence of the clear-sighted observation of animals, which is reflected not only in the knowledge of the appearance of individual species, but also of specific behaviours related to their way of life. It concerns not only domestic animals, like the ass (cf. Gen 49: 14), but also wild representatives of the fauna. References concerning the latter apply to the species perceived as highly dangerous to man and domestic animals, that is the lion (cf. Gen 49: 9), snake (cf. Gen 49: 17) or wolf (cf. Gen 49: 27). Amongst the animals mentioned in the blessing of Jacob one can also distinguish those which aroused admiration because of their appearance, such as the doe (cf. Gen 49: 21). At the same time, it is essential to emphasise the fact that the wealth of animal metaphors is just a tool used to translate "God's address" into human language. 